\title{
Phosphodiesterase Type 5 Inhibitors and Visual Side Effects: A Narrative Review
}

\author{
Francisco Barroso1, MD; João Crispim Ribeiro², MD; Eduardo P. Miranda1, MD \\ ${ }^{1}$ Federal University of Ceara, Fortaleza, Ceara, Brazil \\ ${ }^{2}$ Christus University Center, Fortaleza, Ceara, Brazil \\ ORCID: \\ Francisco Barroso: https://orcid.org/0000-0003-3152-8839
}

\begin{abstract}
Phosphodiesterase type 5 inhibitors such as sildenafil citrate and tadalafil are well known for the treatment of erectile dysfunction. However, their use in the presence of pulmonary hypertension can cause ophthalmologic side effects, including non-arteritic optic ischemic neuropathy, chorioretinopathy, glaucoma, and optic atrophy. The present review aimed to identify these visual side effects and provide recommendations. We identified articles published from January 2000 to March 2019 on diseases arising from the management of sexual dysfunction in urology or pulmonary hypertension in pneumonia that could cause pathologic alterations in eye structure based on a literature search of the MEDLINE electronic database using keywords for the most common adverse effects and different kinds of phosphodiesterase 5 inhibitors. After applying the exclusion criteria, we selected 36 of the 77 articles initially identified to write the narrative review and added 20 additional articles to completely describe the pathological entities. Phosphodiesterase type 5 inhibitors can cause side effects in the eye including ocular surface abnormalities, increased intraocular pressure and glaucoma, uveitis, non-arteritic ischemic neuropathy, chorioretinopathy, retinal occlusion, and visual field changes. There is an increased need for well-performed studies to better understand these side effects, which are common due to the wide use of sildenafil.
\end{abstract}

Keywords: Adverse Effects; Eye Manifestations; Physiological; Review; Sexual Dysfunction; Sildenafil Citrate

J Ophthalmic Vis Res 2021; 16 (2): 248-259

\section{INTRODUCTION}

Erectile dysfunction (ED) is defined as a persistent inability to achieve and/or maintain an erection

Correspondence to:

Francisco Barroso, MD. Manuel Jacare St. 150. Fortaleza, Ceara 60175-110, Brazil.

E-mail: fvictorcbarroso@gmail.com

Received: 03-11-2019Ａccepted: 10-11-2020

\section{Access this article online}

Website: https://knepublishing.com/index.php/JOVR

DOI: 10.18502/jovr.v16i2.9088 to allow satisfactory sexual relations. It is a prevalent condition, with over 18 million men affected worldwide. ED affects an estimated 9.1\% of men aged $40-49$ years, $15.2 \%$ of men aged 50-59 years, $29.4 \%$ of men aged $60-69$ years, and $54.9 \%$ of men older than 70 years. ${ }^{[1]}$ The first line of treatment for ED is phosphodiesterase

This is an open access journal, and articles are distributed under the terms of the Creative Commons Attribution-NonCommercial-ShareAlike 4.0 License, which allows others to remix, tweak, and build upon the work non-commercially, as long as appropriate credit is given and the new creations are licensed under the identical terms.

How to cite this article: Barroso F, Ribeiro JC, Miranda EP Phosphodiesterase Type 5 Inhibitors and Visual Side Effects: A Narrative Review. J Ophthalmic Vis Res 2021;16:248-259. 
type 5 inhibitors (PDE5i). This drug was first developed to treat pulmonary hypertension and muscle spasms; however, its most notable side effect, prolonged erection, soon became the focus of its use in clinical practice. In 1998, the Food and Drug Administration (FDA) approved its use as a clinically effective and safe treatment for ED. ${ }^{[2]}$

There are 11 types of PDEs, all of which function to degrade cyclic adenosine monophosphate (AMPC) to adenosine monophosphate (AMP) and GMPc to guanosine monophosphate $(G M P){ }^{[3]}$ Sildenafil citrate (SC), a selective inhibitor of PDE5i present in the cavernous bodies in the penis, is responsible for smooth muscle relaxation and, consequently, inducing an erection. ${ }^{[1]}$ PDE5i can cross the bloodbrain and blood-retinal barriers and may partially inhibit the PDE 6 enzyme present in the retina, with significant dose-dependent changes in photoreceptors and the optical nerve. ${ }^{[4-6]}$ The main contraindication for the use of PDE5i is its concomitant use with nitrates, which can lead to hypotension and ischemic events. $^{[4]}$

The main reported side effects of PDE5i are headaches, dizziness, blushing, nasal congestion, dyspepsia, and visual changes. The most common visual side effects are photophobia, cyanopsia, and haze. Most of the visual effects can be reversed weeks after stopping use of the medication. ${ }^{[3]}$ Other ophthalmologic disturbances described in the literature include keratitis, ocular surface abnormalities, chorioretinopathy, vessel occlusion, retinal detachment, and optic neuropathy. ${ }^{[1,4,5,7]}$

Considering the wide use of PDE5i, clinicians should know its side effects profile. This study reviewed the most common ocular effects related to the use of PDE5i.

\section{METHODS}

A literature search was conducted through the MEDLINE online electronic database for articles written in English published from January 2000 to March 2019. The reason to delimitate the research to this period was to evaluate recent developments regarding PDE5i and their side effects. Thus, this review aimed to perform a current, but thorough, analysis of published articles. We used the following descriptors in sequence, all of which had to be present in the title of the article: (1) Keratitis OR (2) Surface Abnormalities OR (3) Chorioretinopathy OR (4) Ocular OR (5) Intraocular Pressure OR (6) Glaucoma OR (7) Nonarteritic Anterior Ischemic Optic Neuropathy OR (8) Retinal Occlusion OR (9) Optic Atrophy OR (10) Visual Changes OR (11) Electroretinography OR (12) Uveitis OR (13) Retinal AND (14) Sildenafil AND (15) Phosphodiesterase 5 Inhibitors AND (16) Tadalafil AND (17) Viagra AND (18) Vardenafil AND (19) Avanafil AND (20) Udenafil AND (21) Mirodenafil AND (22) Lodenafil AND 2000/01/01: 2019/03/31. The keywords from 1 to 13 were searched again with AND 14 added; the same process was performed to add keywords 15 to 22.

\section{RESULTS}

We selected 36 of the 77 articles initially identified for the literature review, including both clinical and experimental studies. We also included 20 additional articles to completely describe the pathological entities [Figure 1]. We analyzed the articles for the inclusion and exclusion criteria. The inclusion criteria were articles that had in their titles at least one combination of the descriptors in the search strategy, publications written in the English language, and relevant content in the article regarding the research topic. The exclusion criteria were articles that had in the title or abstract nonophthalmic PDE adverse effects related to PDE5i use; reviews and book chapters; non-original studies including editorials, exam alteration studies, preface and brief communication; duplicate articles, articles written in a language other than English; and unavailable study abstract or full text. We added two studies related to non-arteritic anterior ischemic optic neuropathy (NAION) since our search method identified few studies. Furthermore, we also included 13 letters to editors that described important side effects. We did not find optic atrophy studies related to our topic; similarly, no studies on mirodenafil, udenafil, or lodenafil were identified. Each retrieved article was carefully read and checked for relevance before being included in the review [Figure 1].

We divided the visual side effects into the following categories: keratitis, other surface abnormalities, chorioretinopathy, intraocular 

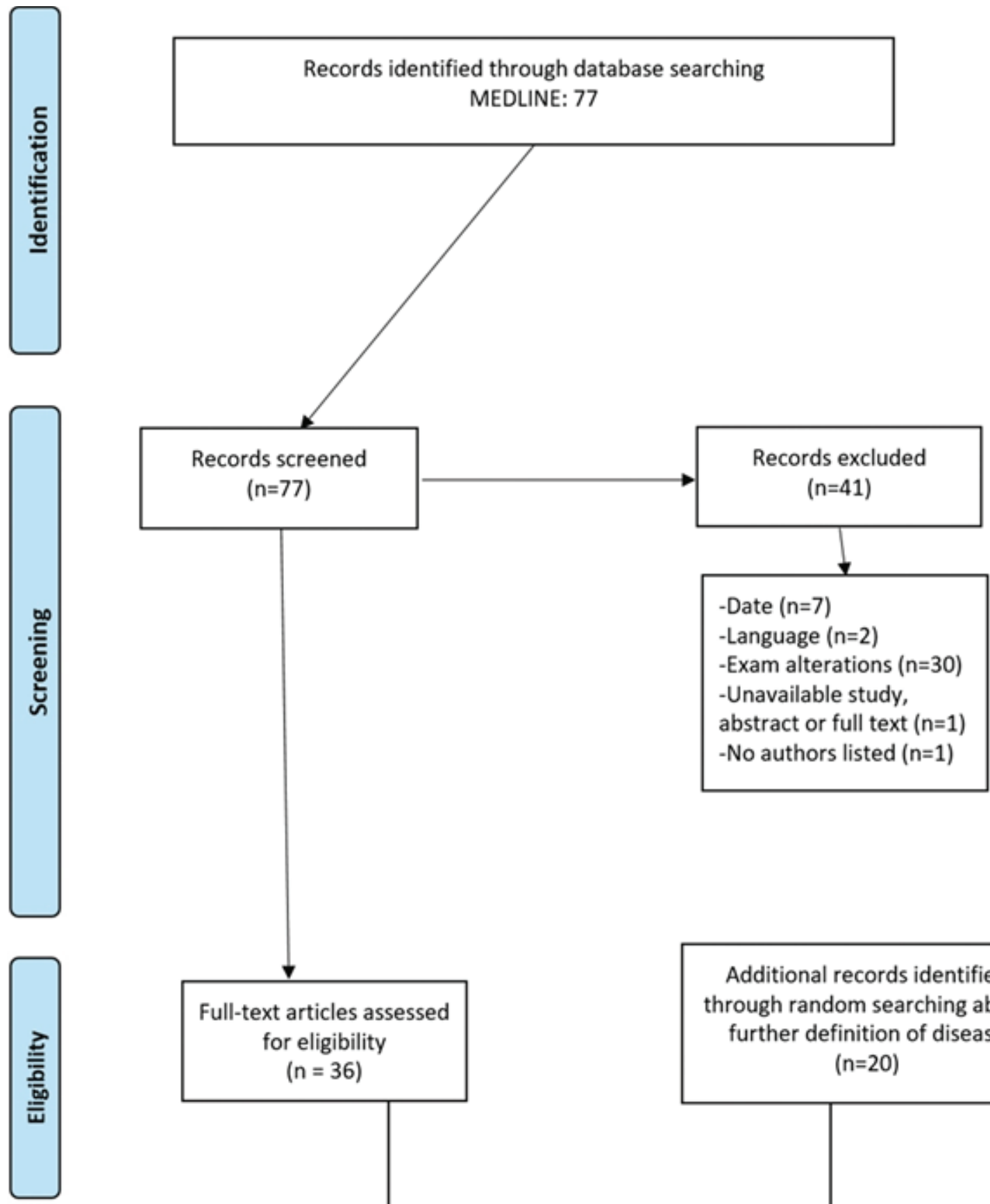

Full-text articles assessed for eligibility $(n=36)$

Additional records identified through random searching about further definition of disease $(n=20)$

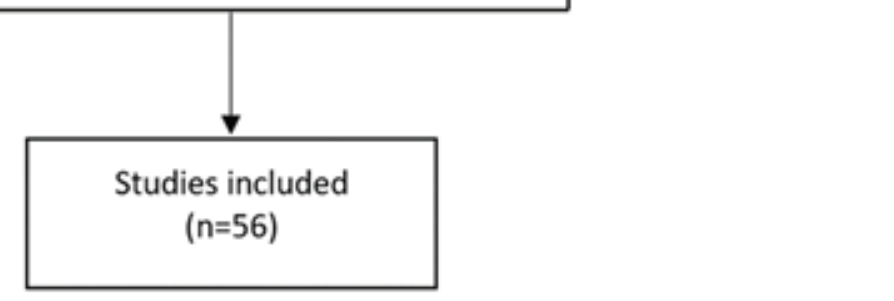

Figure 1. Inclusion and exclusion criteria. 
Table 1. The best studies for each category

Finding

Authors

Concise Methods

Brief Outcomes

Strength of Evidence

Chart 1: Studies Related to Intraocular Pressure Alterations

Increased intraocular Nazari et al. 2017[20] pressure
-110 patients -Weekly sildenafil of $50 \mathrm{mg}$ average dose after 3 months

Wirostko et al. $2012^{[15]} \quad-277$ adults

No Increased intraocular pressure
Ermis et al. 2004 ${ }^{[25]}$

Dündar et al. 2001

Yajima et al. 2000[24]

-28 male volunteers

-14 healthy male volunteers

-Study 1with 16 subjects and study 2 with 48 subjects
-Significantly
differences between intraocular pressure values $-p=0,003$

- Changes in Intraocular Pressure mean showed in $95 \%$ confidence interval ( $\mathrm{Cl}$ )

-No significantly changes in intraocular pressure $-p=0.37$

- No significantly changes in intraocular pressure

-No major changes - Grade B
-Grade B

-Grade B

-Grade B

Grade B

-

\section{Chart 2: Other Surface Abnormalities}

\begin{tabular}{|c|c|c|c|c|}
\hline Finding & Authors & Concise Methods & Brief Outcomes & Strength of Evidence \\
\hline Surface abnormalities & Matieli et al $2016^{[8]}$ & $\begin{array}{l}\text {-Case control with } \\
\text { eyes in case group } \\
\text { and } 13 \text { eyes in control } \\
\text { group }\end{array}$ & $\begin{array}{l}-28 \text { eyes }(70 \%) \text { using } \\
\text { sildenafil, while only } 13 \\
\text { eyes ( } 35 \%) \text { in the } \\
\text { group control }\end{array}$ & - Grade B \\
\hline
\end{tabular}

Chart 3: Keratitis

\begin{tabular}{lllll} 
Finding & Authors & Concise Methods & Brief Outcomes & Strength of Evidence \\
\hline -Keratitis & Matieli et al 2016 & $\begin{array}{l}\text {-Case control with 20 } \\
\text { patients }\end{array}$ & $\begin{array}{l}\text {-One-third of } \\
\text { individuals }\end{array}$ & - Grade B \\
\hline
\end{tabular}

Chart 4: Chorioretinopathy

\begin{tabular}{|c|c|c|c|c|}
\hline Finding & Authors & Concise Methods & Brief Outcomes & Strength of Evidence \\
\hline $\begin{array}{l}\text { Central Serous } \\
\text { Chorioretinopathy }\end{array}$ & Turkuc et al $2013^{[11]}$ & -43 patients treated & $\begin{array}{l}\text {-Sildenafil citrate did } \\
\text { not lead to Central } \\
\text { Serous } \\
\text { Chorioretinopathy }\end{array}$ & -Grade B \\
\hline
\end{tabular}

Chart 5: Uveitis

\begin{tabular}{lllll} 
Finding & Authors & Concise Methods & Brief Outcomes & Strength of Evidence \\
\hline Uveitis & French et a ${ }^{[12]}$ & -Case report & -6 episodes of uveitis & - Grade C
\end{tabular}


Table 1. Continued.

Chart 6: Non-Arteritic Ischemic Optic Neuropathy

\begin{tabular}{|c|c|c|c|c|}
\hline Finding & Authors & Concise Methods & Brief Outcomes & Strength of Evidence \\
\hline & Pomeranz et al ${ }^{[34]}$ & -Literature review & $\begin{array}{l}\text { - } 40 \text { case report } \\
\text { studies reported }\end{array}$ & - Grade C \\
\hline & Galvez-Ruiz et al[ ${ }^{[36]}$ & -Case series & $\begin{array}{l}\text { - } 10 \text { patients who after } \\
\text { regular intake of } \\
\text { Sildenafil presented in } \\
1 \text { eye }\end{array}$ & - Grade C \\
\hline \multirow[t]{4}{*}{ NAION } & Gedik et al ${ }^{[37]}$ & -Case report & $\begin{array}{l}\text { - } 36 \text {-year-old male who } \\
\text { presented blurry vision } \\
\text { in his left eye after } 100 \\
\text { mg Sildenafil intake }\end{array}$ & - Grade C \\
\hline & Hafidi et al ${ }^{[38]}$ & - Case report & $\begin{array}{l}\text { - } 40 \text {-year old man with } \\
\text { vision loss after } 100 \\
\text { mg Sildenafil for two } \\
\text { consecutive days }\end{array}$ & - Grade C \\
\hline & Pomeranz et al ${ }^{[39]}$ & - Case series & $\begin{array}{l}\text { - } 5 \text { patients presented } \\
\text { after ingestion of } 50 \text { to } \\
100 \text { mg of Sildenafil }\end{array}$ & - Grade C \\
\hline & Pomeranz et al ${ }^{[40]}$ & -Case series & $\begin{array}{l}\text { - } 6 \text { of } 7 \text { patients who } \\
\text { took Sildenafil } \\
\text { presented vision loss } \\
\text { within } 24 \text { hours }\end{array}$ & - Grade C \\
\hline
\end{tabular}

Chart 7: Retinal Vessel Occlusion

\begin{tabular}{|c|c|c|c|c|}
\hline Finding & Authors & Concise Methods & Brief Outcomes & Strength of Evidence \\
\hline $\begin{array}{l}\text { Supratemporal retinal } \\
\text { artery branch } \\
\text { occlusion }\end{array}$ & Tripathi et al ${ }^{[33]}$ & -Case report & $\begin{array}{l}69 \text {-year-old male who } \\
\text { presented with sudden } \\
\text { painless vision loss } \\
\text { after two days of } \\
\text { Sildenafil } 100 \mathrm{mg} \\
\text { intake }\end{array}$ & -Grade C \\
\hline \multirow[t]{2}{*}{$\begin{array}{l}\text { Cilioretinal artery } \\
\text { occlusion }\end{array}$} & Hafidi et al ${ }^{[38]}$ & -Case report & $\begin{array}{l}-40 \text {-year-old male who } \\
\text { presented with acute } \\
\text { vision loss after } 2 \text { days } \\
\text { of Sildenafil } 100 \mathrm{mg} \\
\text { intake }\end{array}$ & -Grade C \\
\hline & Murthy et al ${ }^{[47]}$ & -Case report & $\begin{array}{l}\text {-Bilateral concurrent } \\
\text { cilioretinal artery } \\
\text { occlusion in a } \\
\text { 37-year-old female } \\
\text { patient after once daily } \\
\text { for four weeks }\end{array}$ & -Grade C \\
\hline $\begin{array}{l}\text { Cilioretinal vessel } \\
\text { occlusion }\end{array}$ & Pinto et al ${ }^{[49]}$ & -Case report & $\begin{array}{l}\text {-36-year-old male } \\
\text { presented with } \\
\text { cilioretinal vessel } \\
\text { occlusion }\end{array}$ & -Grade C \\
\hline \multicolumn{5}{|l|}{ Chart 8: Visual Change } \\
\hline Finding & Authors & Concise Methods & Brief Outcomes & Strength of Evidence \\
\hline $\begin{array}{l}\text {-Color discrimination } \\
\text { alterations }\end{array}$ & Cordell et al ${ }^{[56]}$ & -Clinical trial & $\begin{array}{l}\text { - Any significant } \\
\text { evidence after } \\
\text { compared Sildenafil } \\
\text { intake for } 6 \text { months } \\
\text { daily }\end{array}$ & -Grade A \\
\hline
\end{tabular}


pressure and glaucoma, uveitis, NAION, and retinal occlusion. We described each category in different sections; namely, epidemiology and pathophysiology, clinical presentation, literature review, and final statement recommendation.

\section{DISCUSSION}

\section{Keratitis}

\section{Epidemiology and pathophysiology}

In less developed countries, infectious keratitis affects about $10 \%$ of the population. Eye injury during agricultural work may predispose infectious agents to cause keratitis. In developed countries, the main cause of this condition is the use of contact lenses.

\section{Clinical presentation}

Keratitis presents intense itching accompanied by redness, pain, photophobia, red eye, and a "gritty" sensation. ${ }^{[4]}$

\section{Literature review}

We did not find any association between PDE5i use for ED and keratitis. However, a case-control study that evaluated ocular toxicity in patients with pulmonary arterial hypertension (PAH) reported a higher incidence of keratitis following chronic SC use. Twenty patients in each group were administered SC from 1 to 60 months at daily doses of $60 \mathrm{mg}$, except for two patients treated with 120 mg per day. One-third of PAH individuals using SC had severe noninfectious bilateral keratitis. Such patients were not contact lens users. A multivariate analysis using a linear regression model showed that dry eye keratitis was significantly associated with SC use. The patients had no other risk factors for dry eye, suggesting that SC use was possibly the main cause of keratitis in these patients. ${ }^{[8]}$

\section{Final statement recommendation}

Patients who will start chronic PDE5i use and have complaints of dry eye or who use contact lenses should be counseled about an increased risk of keratitis. Referral for routine ophthalmic assessment and use of Preservative-free tear substitutes should be considered. ${ }^{[8]}$

\section{Other Surface Abnormalities}

\section{Epidemiology and pathophysiology}

Dry eye disease (DED) is the most common disorder related to surface abnormalities and has been associated with a wide range of traits, including systemic and metabolic conditions.

\section{Clinical presentation}

Dryness, burning, itching, watering, stickiness, and crustiness. $^{[9]}$

\section{Literature review}

Only one article was identified related to this topic. In the same case-control study that evaluated ocular toxicity in PAH patients using SC, all participants presented ocular motility, contrast sensitivity, color vision, Schirmer test, intraocular pressure (IOP), and optical coherence tomography (OCT) within the normal ranges. At least one of these other abnormalities of the ocular surface (tarsal gland dysfunction, conjunctival hyperemia, cornea verticillata, and decreased rupture time) were present in 28 eyes $(70 \%)$ using SC, compared to only 13 eyes (35\%) in the control group. Considering the presence of at least one abnormality in biomicroscopy, SC users (40 eyes of 20 patients) had a statistically higher occurrence of anterior superficial anomalies (Fisher's test $p=$ $0.012)^{[8]}$

\section{Final statement recommendation}

Patients with PAH chronically treated with SC should undergo routine ophthalmologic evaluations to identify ocular surface abnormalities. $^{[8]}$

\section{Chorioretinopathy}

\section{Epidemiology and pathophysiology}

Central serous chorioretinopathy (CSC) typically affects men and women between their third and sixth decades of life. ${ }^{[1]}$ The major risk factors are the state of refraction, systemic hypertension, male sex, older age, black ethnicity, and use of corticosteroids. $^{[10]}$ 


\section{Clinical presentation}

CSC presents as a painless dark, blurred, distorted, dimmed area in the central vision. ${ }^{[1]}$

\section{Literature review}

Two articles on this topic found no association between SC use and CSC. In a prospective study, 43 patients with a mean age of 49.1 years (range 28-67) were treated for ED with SC (50 mg two to three times per week for one month). The patients were evaluated in the first week and at the end of treatment. Macular thickness and volume assessments with OCT did not differ significantly in the central and parafoveal areas $(p>0.05)$. The study concluded that SC in therapeutic doses did not lead to CSC and visual abnormality. ${ }^{[11]}$ French et al ${ }^{[12]}$ studied 577 men aged 59 years and younger with newly diagnosed CSC. To avoid confounding factors, this study did not include individuals with age-related macular degeneration and history of corticosteroid use. The authors found that 111 patients (19.2\%) were prescribed PDE5i before CSC onset, and most (>99\%) were administered SC doses of $100 \mathrm{mg}$ or more [odds ratio: $1.05,95 \%$ confidence interval $(\mathrm{Cl})$ : $0.74-1.22] .{ }^{[12]}$ In contrast, Gordon-Bennett et al ${ }^{[13]}$ reported an inkblot appearance near the fovea in a 51-year-old male patient $24 \mathrm{hr}$ following the ingestion of more than $20 \mathrm{mg}$ tadalafil.

\section{Final statement recommendation}

Patients who are about to start ED treatment with PDE5i should be advised to consult an ophthalmologist in case they experience vision problems. ${ }^{[11]}$

\section{Intraocular Pressure and Glaucoma}

\section{Epidemiology and pathophysiology}

The global prevalence of glaucoma was over 57 million individuals in 2015 and is expected to increase to over 65 and 111 million individuals by 2020 and 2040, respectively. Angle closure and reduction of ocular blood flow are additional mechanisms for the development of glaucoma, which can be triggered by the systemic use of vasodilators, including some PDE5i. ${ }^{[14-17]}$

\section{Clinical presentation}

In primary open-angle glaucoma, which is the most common type of glaucoma, the patient is usually oligosymptomatic and visual changes are present only in advanced stages. In acute-angle glaucoma, sudden visual pain followed by nausea and vomiting is usually the initial presentation. ${ }^{[18]}$

\section{Literature review}

Nine articles discussed this topic. Some authors reported increased IOP after SC use. ${ }^{[19]}$ Nazari et $\mathrm{al}^{[20]}$ reported increased mean IOP after three months in 110 patients aged 42-60 years with weekly SC doses of $25-100 \mathrm{mg}(p$ $=0.002) \cdot{ }^{[20]}$ Furthermore, Chen et $\mathrm{a}^{[21]}$ evaluated the prevalence of self-reported glaucoma in a telephone-based interview in men aged over 40 years. They found that 482 of 7,081 participants reported a diagnosis of glaucoma and the use of $\mathrm{SC}$ in the previous year. However, the dose and frequency of PDE5i intake were not investigated. ${ }^{\text {[1] }}$ Gerometta et al ${ }^{[22]}$ studied nine healthy male and female volunteers aged $18-74$ years, in which the IOP increased 60 min after SC administration ( $p<$ $0.005)$ and returned to the control values within 2 hr. $^{[22]}$ Gerometta et al $^{[23]}$ also demonstrated increased IOP in 21 normal sheep after ingestion of both SC (50 and $100 \mathrm{mg}$ ) and tadalafil. Other research has shown no association between SC use and IOP increase. Yajima et al ${ }^{[24]}$ did not detect any major changes in IOP $24 \mathrm{hr}$ after the oral administration of 10-150 mg SC I. Furthermore, Wirostko et $\mathrm{al}^{[15]}$ reported no changes in IOP among 277 adults with idiopathic $\mathrm{PAH}$ in a doubleblind study using oral SC $(20,40$ or $80 \mathrm{mg})$ or placebo (1:1:1:1) three times daily for 12 weeks. ${ }^{[15]}$ Ermis et $\mathrm{al}^{[25]}$ failed to show any significant effects of SC use on IOP in 28 healthy volunteers with a mean age of 51 years receiving SC (50 and 100 $\mathrm{mg).}{ }^{[25]}$ Moreover, in a double-blind, randomized, placebo-controlled, crossover study, Grunwald et $\mathrm{al}^{[16]}$ reported no significant acute changes on IOP after a single oral dose of SC I $100 \mathrm{mg}$ in 15 subjects aged $63 \pm 14$ years with bilateral chronic open-angle glaucoma. ${ }^{[16]}$ Dündar et al $^{[26]}$ also showed no change in IOP after the administration of a single oral dose of $50 \mathrm{mg} \mathrm{SC}$ to 14 healthy male volunteers tested immediately before and 1 hr after SC administration. ${ }^{[26]}$ 


\section{Final statement recommendation}

There is a lack of prospective randomized trials to determine whether there is a true causal association between PDE5 $i$ use and elevation of IOP leading to glaucoma development or deterioration. However, it is advisable to monitor IOP periodically in high-risk patients ${ }^{[20]}$ [Table 1].

\section{Uveitis}

\section{Epidemiology and pathophysiology}

The prevalence of idiopathic uveitis is similar in studies from different countries. Although the understanding of the pathogenesis of uveitis is evolving, approximately $24-55 \%$ of patients with uveitis have idiopathic or undifferentiated uveitis. ${ }^{[27]}$

\section{Clinical presentation}

Uveitis is an intraocular inflammation due to an inflammation of the uvea presenting as redness and swelling of the uvea. ${ }^{[28]}$

\section{Literature review}

Only one article discussed this topic. The association of PDE5 $i$ and the onset of uveitis is limited to one case report, which described a 38-year-old man diagnosed with Behçet's disease 15 years prior and without any occurrence of uveitis for the past 12 years. After starting SC for ED, he developed recurrent posterior uveitis in his left eye. The uveitis episode started after the second or third dose of SC, with a total of six episodes. ${ }^{[29]}$

\section{Final statement recommendation}

Patients with ED who plan to start PDE5i should be informed of the risk for ocular side effects. If a recurrence of ocular symptoms is observed concomitant to PDE5i intake, patients should be informed to stop treatment. ${ }^{[29]}$

\section{NAION}

\section{Epidemiology and pathophysiology}

The annual incidence of NAION is 1 in 10,000 cases and affects men and women equally.
It is more common in Caucasians than in African, American, and Hispanic descendants. NAION is a multifactorial disorder ${ }^{[30]}$ and is believed to be related to vascular insufficiency in the optic nerve head. The condition is also associated with short posterior ciliary artery dysfunction. However, the mechanisms related to the vasculopathy and ischemia remain unclear and there is no consensus regarding the possible associations between NAION and PDE5i. ${ }^{[31,32]}$

\section{Clinical presentation}

The primary presentation includes acute, painless, unilateral visual loss, which confers an increased risk of contralateral vision loss. The condition may worsen over hours or days, with optic disc edema and an afferent pupillary defect. Altitudinal defects are a more common presentation in the visual field. ${ }^{[16,33]}$

\section{Literature review}

In their literature review, Pomeranz et al ${ }^{[34]}$ described 40 case reports of NAION. Posterior ischemic optic neuropathy was also related to SC use in some letters to the editor. ${ }^{[30,35]}$ GalvezRuiz et al ${ }^{[36]}$ reported a series of 10 patients who presented with NAION with routine exposure to SC (>2-3 times per week) during the weeks and months before the ocular ischemia. NAION was diagnosed based on clinical presentations, fundus features consistent with NAION, and exclusion of other possible etiologies. Half of the patients in the study had a primary episode of unilateral ischemic optic neuropathy. Despite the initial adverse event (first episode of NAION), all patients continued to use the medication and developed a second episode of NAION in the contralateral eye. Only 1 of the 10 patients presented with bilateral simultaneous NAION. ${ }^{[36]}$ Another report described a 36-year-old male patient presenting with blurred vision in his left eye and afferent pupillary defect after the ingestion of $100 \mathrm{mg}$ of SC. Funduscopy revealed hyperemia and edema in the lower portion of the left optic disc. ${ }^{[37]}$ Hafidi et $\mathrm{al}^{[38]}$ reported an acute unilateral visual loss in a previously healthy 40-year-old man after ingestion of $100 \mathrm{mg} \mathrm{SC}$ for two consecutive days before the onset of this visual symptom. In this particular case, 
$\mathrm{SC}$ was associated with NAION and cilioretinal and central retinal vein occlusion (CRVO). ${ }^{[38]}$ Pomeranz et $\mathrm{al}^{[39]}$ (2002) reported on five patients ranging in age from 42 to 69 years after SC ingestion. They demonstrated the characteristic findings of NAION, including altitudinal visual field loss and associated optic disc and/or peripapillary hemorrhages. Pomeranz et $\mathrm{al}^{[39]}$ later reported on seven patients aged 50-69 years who had typical symptoms of NAION within $36 \mathrm{hr}$ after the ingestion of SC for ED. ${ }^{[37,40]}$ However, in a cohort of 8,893 patients prescribed SC by their primary care physicians in England between April and June 1999, NAION was reported only in a 61-year-old patient who had other risk factors for NAION; thus, it was not possible to confirm any association between SC and NAION. ${ }^{[40,41]}$ However, Peter et al ${ }^{[42]}$ reported an NAION case in a patient with no known vasculopathy risk factors.

\section{Final statement recommendation}

A history of NAION should be an absolute contraindication to PDE5i therapy ${ }^{[43]}$ and patients who are at higher risk for NAION (such as small cupto-disc ratio and systemic arterial hypertension) should be counseled and undergo ophthalmologic assessments. $^{[35,38,44]}$

\section{Retinal Vessel Occlusion}

\section{Epidemiology and pathophysiology}

Central retinal artery occlusion (CRAO) occurs in an estimated 1 in 100,000 individuals in the general population and accounts for 1 in 10,000 ophthalmological outpatient visits. ${ }^{[45]}$ An embolism is the most common cause of CRAO. ${ }^{[46]}$

\section{Clinical presentation}

CRAO appears as a sudden, catastrophic visual loss. $^{[46]}$

\section{Literature review}

Tripathi et al ${ }^{[33]}$ reported a case of a 69-year-old man presenting with a sudden painless loss of vision in the left eye two days previously. Fundus examination of the right eye was normal whereas the left eye showed a supratemporal branch retinal artery occlusion. As the patient did not have any of the risk factors for arterial occlusion, a more detailed history was sought. The patient indicated that he had taken SC (100 mg) a few hours before he experienced the loss of vision in his left eye. ${ }^{[33]}$ Murthy et al ${ }^{[47]}$ reported a case of bilateral concurrent CRAO in a 37-year-old female AfricanAmerican patient with sickle cell disease and $\mathrm{PAH}$. She had been treated with tadalafil $(40 \mathrm{mg}$ ) once daily for four weeks. Fluorescein angiography (FA) revealed delayed transit time with areas of blocked fluorescence due to retinal edema, ${ }^{[48]}$ and spectraldomain OCT revealed inner retinal edema in the macula. ${ }^{[47]}$ Hafidi et al ${ }^{[38]}$ reported a case of CRAO and CRVO observed by OCT and FA. The 40year-old male patient was previously healthy and presented with acute visual loss of the left eye after two days of $100 \mathrm{mg} \mathrm{SC}$ use. ${ }^{[47]}$ Pinto et al ${ }^{[49]}$ reported a case of a 36-year-old man with chronic renal failure who was diagnosed with CRVO by FA after ingesting $100 \mathrm{mg} \mathrm{SC}$.

\section{Final statement recommendation}

Acute and severe complaints should alert clinicians to CRAO. Patients with increased risks for thromboembolic events should be counseled about CRAO. Despite the anecdotal cases, it is not possible to establish a link between PDE5i use and CRAO. ${ }^{[47,50]}$

\section{Visual Changes}

\section{Epidemiology and pathophysiology}

Most cases of visual changes after PDE5i are believed to be dose dependent and lead to mild alterations in the visual system. These alterations lead to complaints of blue-tinged vision and increased brightness perception. ${ }^{[51]} \mathrm{SC}$ also inhibits phosphodiesterase type 6 (PDE6), ${ }^{[52]}$ an essential enzyme involved in the activation and modulation of the phototransduction cascade, impairing the ability of PDE6 to shorten the time of integration between the visual system and light level. ${ }^{[53]}$ The sensitivity of SC for PDE6 isoenzymes is thought to be the basis for the reduced electrophysiological response on electroretinograms (ERG) in patients prescribed $50 \mathrm{mg} \mathrm{SC}$, as well as the transient color vision abnormalities more likely to be observed with higher doses of SC. ${ }^{[54]}$ 


\section{Clinical presentation}

Patients report changes related to color perception. ${ }^{[55]}$

\section{Literature review}

In a comparative case series study, Matieli et al ${ }^{[8]}$ analyzed the visual effects of SC use for PAH by assessing symptoms such as bluish vision, photophobia, and green or blue or yellow patterns on Farnsworth D15-Color Test Saturated Panels. SC was used from 1 to 60 months. The SC user and control groups included 17 women each. Onethird of the treated group showed severe bilateral keratitis. In contrast, Cordell et al $^{[56]}$ randomized 244 subjects to receive tadalafil ( $5 \mathrm{mg}, 85$ patients), SC (50 mg, 77 patients), or placebo (82 patients) daily for six months. No significant differences in the visual function of color discrimination by the Farnsworth-Munsell 100-Hue Color Vision Test were observed between the treatment and placebo groups. $^{[56]}$

\section{Final statement recommendation}

Despite its low occurrence, patients should be counseled about transient color changes associated with PDE5i use for ED or PAH. ${ }^{[8]}$

\section{SUMMARY}

PDE5 $i$ are one of the most prescribed drugs worldwide, with a very good safety profile. However, NAION, chorioretinopathy, and color changes are important issues reported in the literature. Although these visual side effects have been reported in patients using PDE5i, there is not enough evidence to prove a causal association. Given the low incidence of such side effects, these should not preclude the usual indications for PDE5i. However, patients with histories of ophthalmologic conditions or optic nerve issues or those at high risk for any eye disease require specific clearance before the commencement of therapy.

\section{Acknowledgement}

The authors would like to thank Federal University of Ceara and Christus University Center for collaboration and Editage (www.editage.com) for English language editing.

\section{Financial Support and Sponsorship}

Nil.

\section{Conflicts of Interest}

There is no conflict of interest.

\section{REFERENCES}

1. Selvin E, Burnett AL, Platz EA. Prevalence and risk factors for erectile dysfunction in the US. Am J Med 2007;120:151157.

2. Kehat R, Bonsall DJ, North R, Connors B. Ocular findings of oral sildenafil use in term and near-term neonates. $J$ AAPOS 2010;14:159-162.

3. Sowka JW, Neiberg MN, Vollmer LA. Optic atrophy after sildenafil use. Optometry 2007;78:122-128.

4. Hom MM, Nguyen AL, Bielory L. Allergic conjunctivitis and dry eye syndrome. Ann Allergy Asthma Immunol 2012;108:163-166.

5. Keay L, Stapleton F, Schein O. Epidemiology of contact lens-related inflammation and microbial keratitis: a 20year perspective. Eye Contact Lens 2007;33:346-353, discussion 62-63.

6. Gupta N, Tandon R, Gupta SK, Sreenivas V, Vashist P. Burden of corneal blindness in India. Indian J Community Med 2013;38:198-206.

7. Nirmalan PK, Katz J, Tielsch JM, Robin AL, Thulasiraj RD, Krishnadas $\mathrm{R}$, et al. Ocular trauma in a rural south Indian population: the Aravind Comprehensive Eye Survey. Ophthalmology 2004;111:1778-1181.

8. Matieli L, Berezovsky A, Salomao SR, Allemann N, Martins EN, Hirai FE, et al. Ocular toxicity assessment of chronic sildenafil therapy for pulmonary arterial hypertension. Graefes Arch Clin Exp Ophthalmol 2016;254:1167-1174.

9. The definition and classification of dry eye disease: report of the Definition and Classification Subcommittee of the International Dry Eye WorkShop (2007). Ocul Surf 2007;5:75-92.

10. Damar E, Toklu Y, Tuncel A, Balci M, Aslan Y, Simsek S, et al. Does therapeutic dose of sildenafil citrate treatment lead to central serous chorioretinopathy in patients with erectile dysfunction? Am J Mens Health 2013;7:439-443.

11. Turkcu FM, Yuksel H, Sahin A, Murat M, Bozkurt Y, Caca I. Central serous chorioretinopathy due to tadalafil use. Int Ophthalmol 2013;33:177-180.

12. French DD, Margo CE. Central serous chorioretinopathy and phosphodiesterase-5 inhibitors: a case-control postmarketing surveillance study. Retina 2010;30:271274.

13. Gordon-Bennett P, Rimmer T. Central serous chorioretinopathy following oral tadalafil. Eye 2012;26:168-169.

14. Kapetanakis VV, Chan MP, Foster PJ, Cook DG, Owen CG, Rudnicka AR. Global variations and time trends in the prevalence of primary open angle glaucoma (POAG): a systematic review and meta-analysis. $\mathrm{Br} J$ Ophthalmol 2016;100:86-93. 
15. Wirostko BM, Tressler C, Hwang LJ, Burgess G, Laties AM. Ocular safety of sildenafil citrate when administered chronically for pulmonary arterial hypertension: results from phase III, randomised, double masked, placebo controlled trial and open label extension. BMJ 2012;344:e554.

16. Grunwald JE, Jacob SS, Siu K, Piltz J, Dupont J. Acute effects of sildenafil citrate (Viagra) on intraocular pressure in open-angle glaucoma. Am J Ophthalmol 2001;132:872874.

17. Lee WJ, Seong M. Sildenafil citrate and choroidal thickness. Retina 2011;31:1742; author reply -3.

18. Garg A, Gazzard G. Selective laser trabeculoplasty: past, present, and future. Eye 2018;32:863-876.

19. Ramasamy B, Rowe F, Nayak H, Peckar C, Noonan C. Acute angle-closure glaucoma following sildenafil citrate-aided sexual intercourse. Acta Ophthalmol Scand 2007;85:229-230.

20. Nazari A, Tabrizi YT, Mokhtaree M. Effect of periodic sildenafil dosage on intraocular pressure in patients with erectile dysfunction. Electron Physician 2017;9:52295232.

21. Chen SP, Singh K, Lin SC. Use of phosphodiesterase inhibitors and prevalence of self-reported glaucoma in the United States. PLoS ONE 2017;12:e0183388.

22. Gerometta R, Alvarez LJ, Candia OA. Effect of sildenafil citrate on intraocular pressure and blood pressure in human volunteers. Exp Eye Res 2011;93:103-107.

23. Gerometta R, Alvarez LJ, Candia OA. Effects of sildenafil and tadalafil on intraocular pressure in sheep: implications for aqueous humor dynamics. Invest Ophthalmol Vis Sci 2010;51:3139-3144.

24. Yajima T, Yajima Y, Koppiker N, Grunwald JE, Laties AM. No clinically important effects on intraocular pressure after short-term administration of sildenafil citrate (Viagra). Am J Ophthalmol 2000;129:675-676.

25. Ermis SS, Inan UU, Samli M, Ozturk F. Acute effects of sildenafil on Humphrey visual field and intraocular pressure. Int Ophthalmol 2004;25:69-72.

26. Dundar SO, Dundar M, Kocak I, Dayanir Y, Ozkan SB. Effect of sildenafil on ocular haemodynamics. Eye 2001;15:507510.

27. Han YS, Rivera-Grana E, Salek S, Rosenbaum JT. Distinguishing uveitis secondary to sarcoidosis from idiopathic disease: cardiac implications. JAMA Ophthalmol 2018;136:109-115.

28. Krishna U, Ajanaku D, Denniston AK, Gkika T. Uveitis: a sight-threatening disease which can impact all systems. Postgrad Med J 2017;93:766-773.

29. Isik M, Kilic L, Dogan I. Recurrent uveitis due to sildenafil usage in a patient with Bechet's disease. Rheumatol Int 2013;33:803.

30. Su DH, Ang PS, Tow SL. Bilateral posterior ischemic optic neuropathy associated with use of sildenafil. $J$ Neuroophthalmol 2008;28:75.

31. Li A, Li L, Li M, Shi X. A new characterization for nonarteritic anterior ischemic optic neuropathy. Int J Clin Exp Med 2015;8:18681-18688.

32. Boshier A, Pambakian N, Shakir SA. A case of nonarteritic ischemic optic neuropathy (NAION) in a male patient taking sildenafil. Int J Clin Pharmacol Ther 2002;40:422423.
33. Tripathi A, O'Donnell NP. Branch retinal artery occlusion; another complication of sildenafil. $\mathrm{Br} J$ Ophthalmol 2000;84:934-935.

34. Pomeranz HD. Erectile dysfunction agents and nonarteritic anterior ischemic optic neuropathy. Neurol Clin 2017;35:17-27.

35. Coca MN, Morgan ML, Gupta P, Elkeeb A, Lee AG. Bilateral posterior ischemic optic neuropathy associated with the use of Sildenafil for pulmonary hypertension. Can J Ophthalmol 2016;51:e96-e99.

36. Galvez-Ruiz A, Arishi N. Sequential, non-arteritic anterior ischemic optic neuropathy in patients taking sildenafil: a report of ten cases. Saudi J Ophthalmol 2013;27:241-246.

37. Gedik S, Yilmaz G, Akova YA. Sildenafil-associated consecutive nonarteritic anterior ischaemic optic neuropathy, cilioretinal artery occlusion, and central retinal vein occlusion in a haemodialysis patient. Eye 2007;21:129-130.

38. Hafidi Z, Handor H, Laghmari M, Daoudi R. Cilioretinal artery and central retinal vein occlusion after sildenafil use. Emerg Med J 2014;31:535.

39. Pomeranz HD, Smith KH, Hart WM Jr, Egan RA. Sildenafilassociated nonarteritic anterior ischemic optic neuropathy. Ophthalmology 2002;109:584-587.

40. Pomeranz HD, Bhavsar AR. Nonarteritic ischemic optic neuropathy developing soon after use of sildenafil (Viagra): a report of seven new cases. J Neuroophthalmol 2005;25:9-13.

41. Oguz H. Sildenafil-associated vascular casualties. Eye 2007;21:676-677; author reply 7-8.

42. Peter NM, Singh MV, Fox PD. Tadalafil-associated anterior ischaemic optic neuropathy. Eye 2005;19:715-717.

43. Pepin S, Pitha-Rowe I. Stepwise decline in visual field after serial sildenafil use. J Neuroophthalmol 2008;28:76-77.

44. Fraunfelder FW, Fraunfelder FT. Central serous chorioretinopathy associated with sildenafil. Retina 2008;28:606-609.

45. Varma D, Lee AW, Chen CS. Reply: 'a review of central retinal artery occlusion: clinical presentation and management'. Eye 2014;28:1270.

46. Rudkin AK, Lee AW, Chen CS. Vascular risk factors for central retinal artery occlusion. Eye 2010;24:678-681.

47. Murthy RK, Perez L, Priluck JC, Grover S, Chalam KV. Acute, bilateral, concurrent central retinal artery occlusion in sickle cell disease after use of tadalafil (Cialis). JAMA Ophthalmol 2013;131:1471-1473.

48. Bertolucci A, Latkany RA, Gentile RC, Rosen RB. Hemiretinal artery occlusion associated with sexual activity and sildenafil citrate (Viagra). Acta Ophthalmol Scand 2003;81:198-200.

49. Pinto LM, Morekar S, Mahashur AA. Central retinal vein occlusion in a patient after being commenced on sildenafil citrate for pulmonary arterial hypertension. Indian J Chest Dis Allied Sci 2009;51:249-251.

50. Li AS, Pomeranz HD. Food and drug administration adverse event reports of retinal vascular occlusions associated with phosphodiesterase type 5 inhibitor use. J Neuroophthalmol 2016;36:480-481.

51. Kinoshita J, Iwata N, Shimoda H, Kimotsuki T, Yasuda M. 
Sildenafil-induced reversible impairment of rod and cone phototransduction in monkeys. Invest Ophthalmol Vis Sci 2015;56:664-673.

52. Laties AM, Fraunfelder FT. Ocular safety of Viagra, (sildenafil citrate). Trans Am Ophthalmol Soc 1999;97:115125; discussion 25-28.

53. Stockman A, Sharpe LT, Tufail A, Kell PD, Ripamonti C, Jeffery $G$. The effect of sildenafil citrate (Viagra) on visual sensitivity. J Vis 2007;7:4.
54. Farooq MU, Naravetla B, Moore PW, Majid A, Gupta R, Kassab MY. Role of sildenafil in neurological disorders. Clin Neuropharmacol 2008;31:353-362.

55. Sinha S, Pathak-Ray V, Ahluwalia H, Morgan JE. Viagra or what? Eye 2004;18:446-448.

56. Cordell WH, Maturi RK, Costigan TM, Marmor MF, Weleber RG, Coupland SG, et al. Retinal effects of 6 months of daily use of tadalafil or sildenafil. Arch Ophthalmol 2009;127:367-373. 